\title{
EFFECT OF MID-TERM CROPPING SYSTEM ADOPTION ON SOIL CHEMICAL PROPERTIES AT CHANGUNARAYAN MUNICIPALITY, BHAKTAPUR, NEPAL
}

(iD) Saroj Koirala
(iD) Santosh Shrestha ${ }^{2+}$
(i) Prashanta Raut ${ }^{3}$
(D) Bikram Pandey ${ }^{4}$
(i) Arbindra
Timilsina $^{5}$

Article History

Received: 26 May 2021 Revised: 29 June 2021 Accepted: 3 August 2021 Published: 24 August 2021

\section{Keywords}

Acidity

Changunarayan

C: $\mathrm{N}$

Cropping system

Crop rotation

Paddy-wheat

Paddy-wheat-vegetables

Polyhouse.

\author{
${ }^{\prime}$ Institute of Mountain Hazards and Environment, Chinese Academy of \\ Sciences, Chengdu, China; Agricultural Technology Center, Lalitpur, Nepal. \\ Email:sarojkoirala1@gmail.com Tel:+977-9869501692 \\ ${ }^{2}$ Department of Soil Science, Institute of Agricultural and Animal Science, \\ Kathmandu, Nepal; Agricultural Technology Center, Lalitpur, Nepal. \\ Email: santoshshrestha.soil@gmail.com Tel: +977-9840012016 \\ 'Agricultural Technology Center, Lalitpur, Nepal. \\ Email:rautprasant@gmail.com Tel:+977-986976883s \\ ${ }^{4}$ University of Chinese Academy of Sciences, Beijing, China. \\ Email:bikram_pandey4@yahoo.com Tel:+977-9849555851 \\ ${ }^{5}$ Key Laboratory of Agricultural Water Resources, Hebei Key Laboratory of \\ Soil Ecology, Center for Agricultural Resources Research, Institute of \\ Genetics and Developmental Biology, Chinese Academy of Sciences, \\ Shijiazhuang, China. \\ Email:arbintms@sjziam.ac.cn Tel: +86-18533127091
}

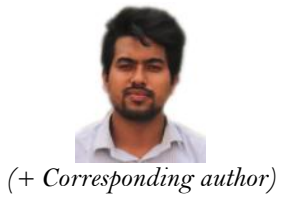

(+ Corresponding author)

ABSTRACT

Soil chemical properties plays a crucial role in crop yield. In this study, we evaluated the chemical properties of soils under three different cropping systems practiced for more than five years in Changunarayan municipality of Bhaktapur district of Nepal. The cropping systems includes- (i) cultivation inside polyhouse (Treatment A: polyhouse), (ii) paddy-wheat rotation (Treatment B: P-W), and (iii) paddy-wheatvegetable rotation (Treatment $\mathrm{C}$ : $\mathrm{P}-\mathrm{W}-\mathrm{V}$ ). Thirty-nine composite samples (13 replicates from each site) were taken from the area based on variation in landforms. Soil $\mathrm{pH}$, organic matter (\%), total nitrogen (\%), available phosphorus $\left(\mathrm{mgkg}^{-1}\right)$, and available potassium $\left(\mathrm{mgkg}^{-1}\right)$ were evaluated for each sample. The study revealed that the soil $\mathrm{pH}$ was acidic and ranges between 4.71 and 5.39, organic matter (1.6-2.39\%), total nitrogen (0.091-0.13\%), phosphorus (4.48-29.24mg kg-1) and potassium (88.04-109.52 $\left.\mathrm{mg} \mathrm{kg}^{-1}\right)$. A significant lower mean $\mathrm{pH}$ (4.71), and higher mean organic matter (2.39\%), total nitrogen $(0.13 \%)$ and available phosphorus $\left(29.24 \mathrm{mgkg}^{-1}\right)$ were observed in cultivation under polyhouse. Incorporation of vegetable in paddy-wheat system gave significant $(p<0.05)$ higher accumulation of soil phosphorus and consistently raised other nutrient status. Moreover, cultivation under polyhouse raised C:N ratio (10.55) significantly than other system. This finding can be relevant to wide range of readers that focus on soil chemical properties and can be used in developing future research strategy and sustainable soil management system in the area.

Contribution/Originality: In this paper we analyzed the impact of different cropping system over soil quality.

\section{INTRODUCTION}

Cropping system represents the total sequence and arrangement of several crops, way of their cultivation and their relationship with farm available resources [1,2]. It directly affects soil quality or soil health based on crop selected, their yearly rotation, fertilizer application, tillage techniques [3, 4]. Soil quality is measure of different soil physical and chemical parameters such as organic carbon content, nutrient status such as macro and micro nutrients 
and other parameters and functioning ability of soil [5]. Soil quality is to be considered with prolonged cropping system as it defines the sustainability and stability in terms of productivity and environment [6].

Laudicina, et al. [7] measured significant variation in soil organic carbon in response to cropping system (wheat only \& wheat-bean) and tillage management practices. They found higher carbon content in monoculture (wheat only) and no till system. Soil carbon fraction are altered by dual action of cropping system and soil management practices [8]. A significant lower $\mathrm{pH}$ was observed in monocropping and highest $\mathrm{pH}$ was observed in Cauliflower-Maize rotation [9]. Similarly Loria, et al. [10] revealed that higher soil carbon, soil nitrogen, phosphorus and potassium were observed in vegetable cultivation compared to cereals.

In context of Nepal, commonly practiced cropping system is maize based and paddy based in mid-land (hilly) and lowland (Terai) regions, respectively [11]. Along with cropping system, application of fertilizer or manures also determines the soil nutrient status which totally depend upon cropping system or crops incorporated in the system. Shrestha [12] reported that use of farm yard manure had been reduced by $25-30 \%$ in hills whereas, according to Maskey, et al. [13], approximately $91 \%$ of farmers in hilly area applied farm yard manure in their cropping system which in long term affects soil fertility. Shrestha, et al. [11] found that soil carbon content was higher in uncultivated system which goes on decreasing in cultivated system of $<10$ years and was least in cultivated land for $>50$ years for both warm temperate and sub-tropical agroecological zones. Recently, Ojha, et al. [14] suggested to increase potassic fertilizer rate by 1.5-2.5 times than recommended dose in Nepal due to impact of long term paddy-wheat cropping system.

Therefore, with limited study prioritizing the effect of commonly practiced cropping system in Nepal, this study aims to determine the effect of cropping system on soil chemical parameters namely $\mathrm{pH}$, nitrogen, phosphorus, potassium and organic matter. Understanding such impacts will help to analyze the appropriate cropping system sustainability based on soil cost incurred in long term adoption. Our findings can be a reference to sustainable soil management and further can be used in developing future research strategy targeting similar cropping preferences.

\section{METHODOLOGY}

\subsection{Study Area}

Study area of the research is dominated by ethnic communities (Newar) situated in Changunarayan municipality-07, Bhaktapur district of Nepal. It extends from latitude $27^{\circ} 41^{\prime} 24.63^{\prime \prime} \mathrm{N}$ and longitude $85^{\circ} 28^{\prime}$ 19.08" E to latitude of $27^{\circ} 41^{\prime} 26.94^{\prime \prime} \mathrm{N}$ and longitude of $85^{\circ} 29^{\prime} 1.9^{\prime \prime} \mathrm{E}$ Figure 1. The altitude of site varies between 1362 masl to 1505 masl. Also, the site predominantly had a loamy textured soil with variation in slope, altitude and aspect.

Three major cropping system are prevalent in the study area: paddy-wheat, paddy-wheat-vegetables, and tomato/vegetables under polyhouse that are in practice for past five years. Paddy-wheat system is totally rain-fed with addition of urea as fertilizer. Few $(30 \%)$ sample points in paddy-wheat system were found that added with phosphoric fertilizer (Diammonium phosphate-DAP) and potassic fertilizer (Muriate of potash-MOP). Paddywheat-vegetable practices adds urea, DAP and MOP with little addition of farm yard manure. High dose of urea, DAP and MOP, other micronutrients and compost is followed inside polyhouse with often irrigation.

\subsection{Research Design and Soil Sampling}

Three major treatments taken were vegetables cultivation inside polyhouse (Treatment A), paddy-wheat (P-W: Treatment B), and paddy-wheat-seasonal vegetables (P-W-V: Treatment C). Composite soil samples were made from five sum samples taken randomly from depth of $0-20 \mathrm{~cm}$ with help of auger for each treatment depending upon the variability of land. Total 13 composite samples were made for each treatment which makes total 39 soil samples for all the treatments. Geo points were also recorded for each composite sample collected. 


\subsection{Laboratory Analysis}

Collected samples were analyzed in soil laboratory of Agricultural Technology Center (ATC), Kupondole, Lalitpur (Nepal) accounting to total nitrogen (\%), available phosphorus $\left(\mathrm{mgkg}^{-1}\right)$, available potassium $\left(\mathrm{mgkg}^{-1}\right)$, soil $\mathrm{pH}$, organic matter $(\%)$ and soil texture. The methods adopted to calculate the soil parameters are mentioned in Table 1.
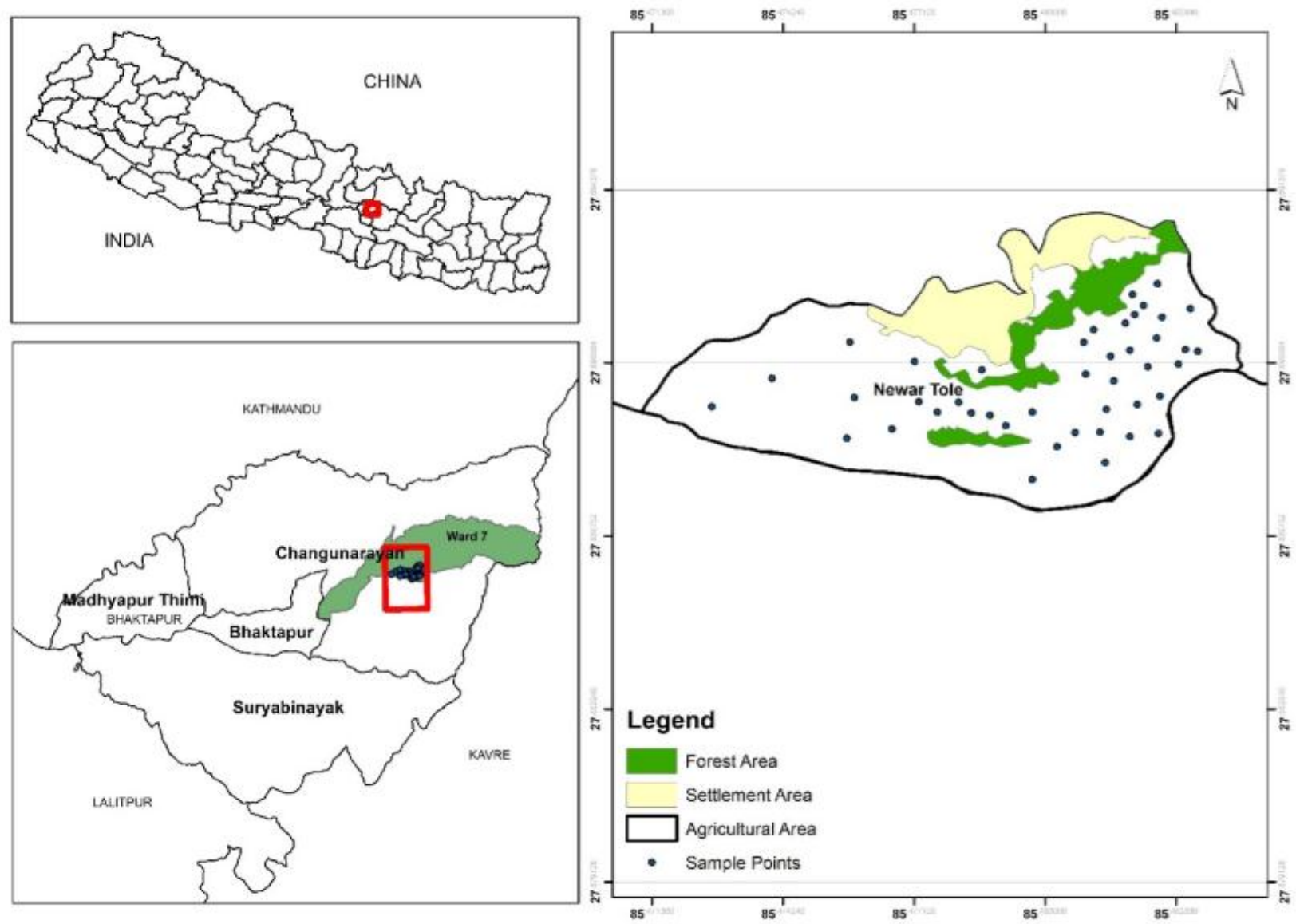

Figure-1. Map of study area.

Table-1. Soil parameters and laboratory methods adopted at Agricultural Technology Center, Kupondole, Lalitpur

\begin{tabular}{l|l|l|l|l}
\hline S.N & Parameter & Unit & Methods & Reference \\
\hline 1 & Total Nitrogen & $\%$ & Kjeldahl Method & $\begin{array}{l}\text { Bremner } \\
\text { Mulvaney }[15]\end{array}$ \\
\hline 2 & Available phosphorus & $\mathrm{mgkg}^{-1}$ & Modified Olsen's Bicarbonate Method & Olsen $[16]$ \\
\hline 3 & Available potassium & mgkg $^{-1}$ & Neutral Ammonium Acetate Method & Simard $[17]$ \\
\hline 4 & Soil pH & - & $1: 2.5$ Potentiometric method & SMD [18] \\
\hline 5 & Soil organic matter & $\%$ & Walkley Black Method & $\begin{array}{l}\text { Walkley and Black } \\
{[19]}\end{array}$ \\
\hline 6 & Soil texture & - & Hydrometer method & Jackson [20] \\
\hline
\end{tabular}

\subsection{Statistical Analysis}

Data from the laboratory were analyzed using one-way analysis of variance (ANOVA) in R (V 4.0.5, R Core Team). Post-hoc analysis was performed for significant means with Duncan multiple range test at $5 \%$ level of significance. Moreover, following Ramamoorthy and Bajaj [21] we calculated nutrient index of the site. Visualization of data was processed with Sigma Plot (V14.0, Systat Software Inc). 


\section{RESULT AND DISCUSSION}

\subsection{Soil pH}

Multiple factors modify the soil $\mathrm{pH}$, for example, the accumulation of organic matter, harvesting high yielding crops, and nitrification of applied nitrogen [22, 23]. Soil acidity greatly impact the soil fertility at soil pH values < 5.5 [23]. Therefore, understanding the $\mathrm{pH}$ values of agricultural soil is critical for increasing the crop yield. Results indicate that the soil under polyhouse has significantly $(\mathrm{p}<0.05)$ lowest $\mathrm{pH}(4.78)$ compared to paddy-wheatvegetable (5.33) and paddy-wheat (5.37) Figure 2. Soils in the study area were moderately acidic to strongly acidic Table 2. This suggests that the parent material in the study area is acidic. Unlike other studies [24, 25], our findings indicated lower $\mathrm{pH}$ resulting from vegetable cultivation under polyhouse. The difference in soil management practice and agricultural inputs inside polyhouse compared to other treatments might have cause the reduction of soil pH. Increased quantity of nitrogen based fertilizer can increase soil acidity inside polyhouse [26]. However, vegetable crops like tomatoes are mostly cultivated inside polyhouse which prefer soils with neutral pH. $[27]$.

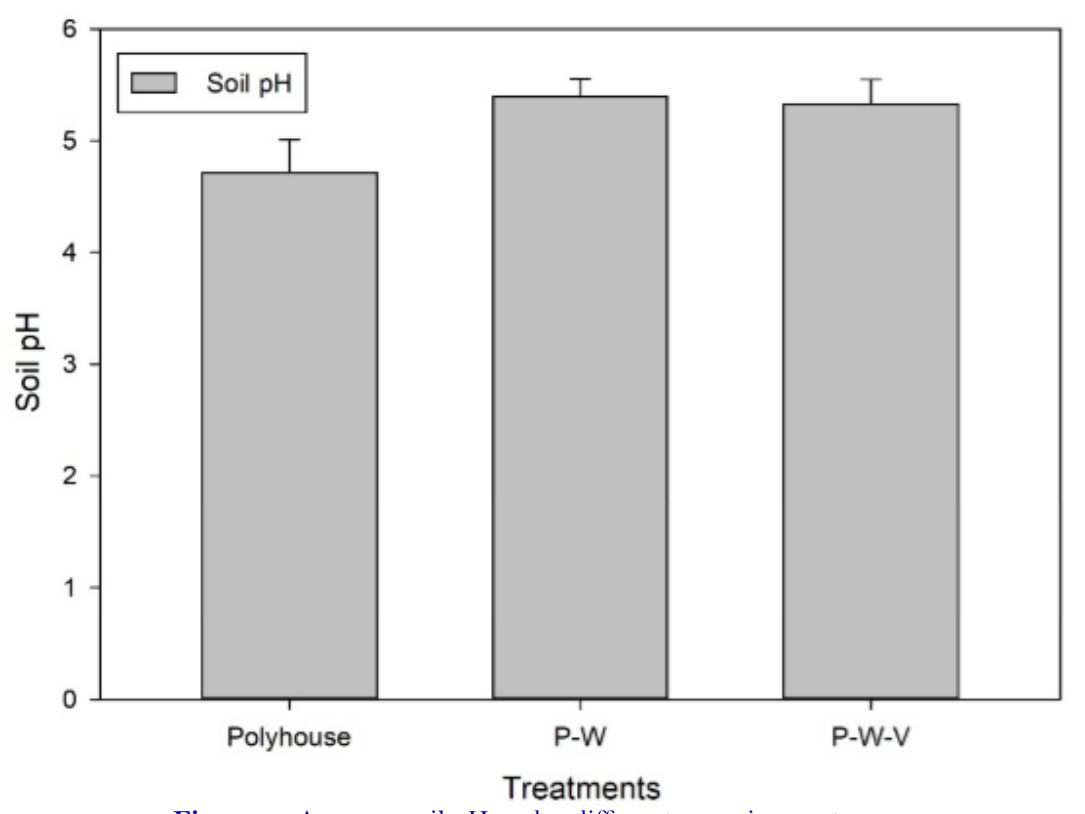

Figure-1. Average soil pH under different cropping systems.

\subsection{Organic Matter (OM)}

Soil organic matters have direct role on soil fertility as its oxidation in soil can provide nutrition like nitrogen, phosphorus and sulphur to plants [28, 29]. Therefore, knowledge of soil organic matter is essential for understanding soil fertility. An accumulation of organic matter on the soil was significantly $(\mathrm{p}<0.05)$ higher in vegetable cultivation under polyhouse $(2.37 \pm 0.13)$ compared to other two cropping systems Table 2 . However, cultivation of vegetables in the paddy wheat cropping system did not improve the organic matter contents Figure 3. The mean organic matter reported in our study were less compared to previous study [28]. Organic matter is rapidly lost when input is reduced [30]. Therefore, the difference in organic matter in various site can be due to difference in input rate.

An addition of organic material like animal manures and compost increases the soil organic matters in field [28]. Moreover, addition of organic amendments such as mustard oil cake, compost and farm yard manure is common inside tomato cultivation polyhouse in Nepal [31] that might have caused organic matter fraction to rise than other treatments. Frequent cultivation might break down the OM content of the soil and remove the essential nutrient from the soil [32]. Therefore, the less amount of OM in the sample in the paddy-wheat and paddy-wheat- 
vegetable cropping area might be due to seasonal crop rotation without addition of required organic amendments and associated soil disturbance through tillage.

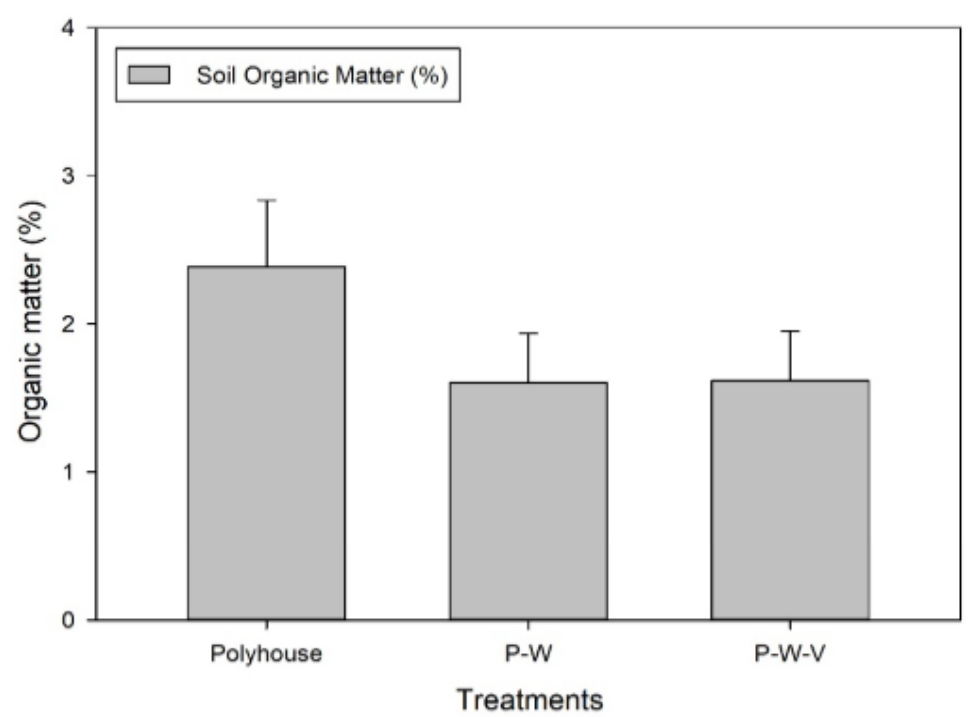

Figure-2. Average soil organic matter (OM\%) under three different cropping systems.

\subsection{Soil Available Phosphorus and Available Potassium}

Phosphorus $(\mathrm{P})$ and potassium $(\mathrm{K})$ are important nutrient required for plant growth. Available soil $\mathrm{P}$ and $\mathrm{K}$ can be directly used by plants which promotes soil fertility and plants growth [33]. Our findings showed that cultivation under tunnel increased phosphorus $\left(29.15 \mathrm{mg} \mathrm{kg}^{-1}\right)$ and potassium $\left(108.88 \mathrm{mg} \mathrm{kg}^{-1}\right)$ content of soil Table 2. On the other hand, paddy-wheat cropping system shows least accumulation of phosphorus $\left(4.95 \mathrm{mg} \mathrm{kg}^{-1}\right)$ and potassium (90.02 $\left.\mathrm{mg} \mathrm{kg}^{-1}\right)$, while addition of vegetable in paddy wheat cropping system however have positive impact on accumulation of phosphorus $\left(6.97 \mathrm{mg} \mathrm{kg}^{-1}\right)$ and potassium $\left(91.04 \mathrm{mg} \mathrm{kg}^{-1}\right)$ Figure 4 . The available soil phosphorus and potassium reported in our study are similar with previous study [34].

Soil phosphorus is major nutrient required for Adenosine triphosphate (ATP) transfer in the cell and photosynthesis in plants [35]. Depletion of available $\mathrm{K}^{+}$in soils causes various negative impacts that mainly includes less utilization of other nutrient like nitrogen and phosphorus, and decrease in yield and ultimately income [36]. The lower amount of these elements in the study sites might suggest additional application of fertilizers for increased productivity and income.

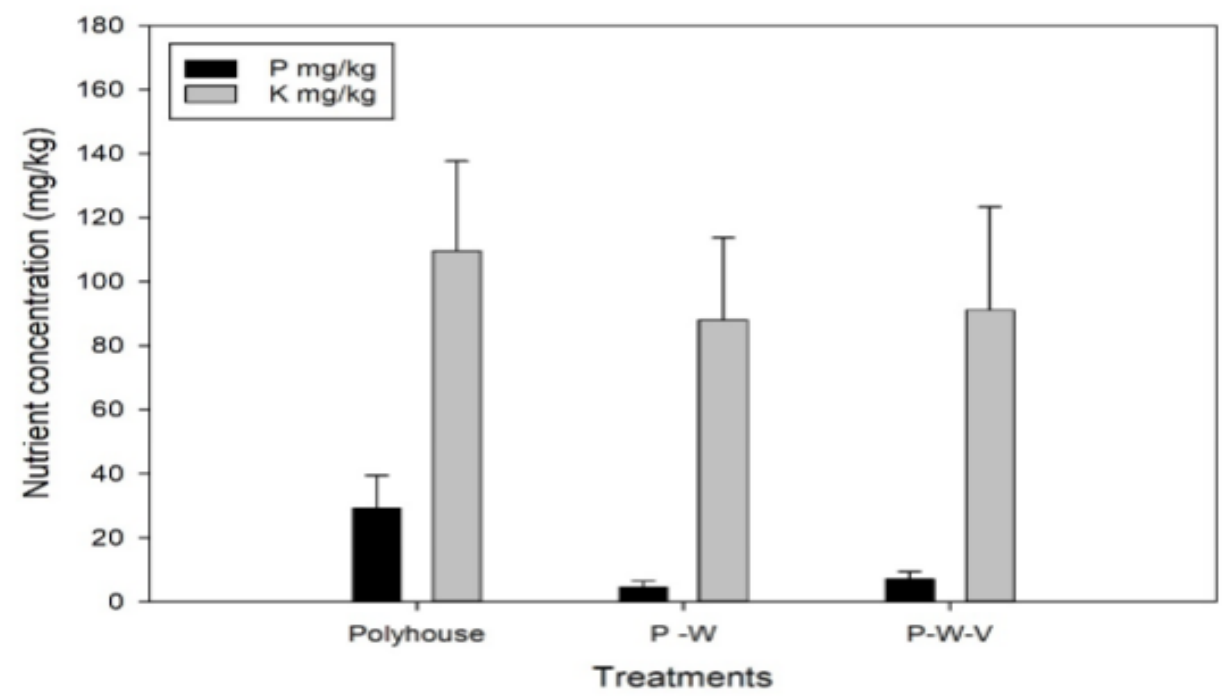

Figure-4. Average Soil potassium and phosphorus (mg kg-1) under three different cropping system. 


\subsection{Soil Nitrogen}

Nitrogen is one of the major nutrients required for proper growth and development of plants, especially food crops and are closely related to economy of crop production. Soil nitrogen is important for leaf growth and promote photosynthesis [37]. Therefore, understanding the nitrogen content of the agricultural soil is important for crop growth and productivity. In this study, we found that the percentage of nitrogen content in the soil shows significant $(\mathrm{p}<0.05)$ differences among three treatments Table 2 . The highest soil nitrogen was found in polyhouse (0.13\%) followed by paddy-wheat cultivation (0.097\%) and paddy-wheat-vegetable farming (0.091\%) Figure 5. Our findings are consistence with Panday, et al. [25]; Khadka, et al. [38]; Shrestha [39] who reported that the continuous application of nitrogenous based fertilizer might be the explanatory factor for high total nitrogen in the soil of study sites. While difference in the nitrogen content among ecosystems could be due to difference in management practices.

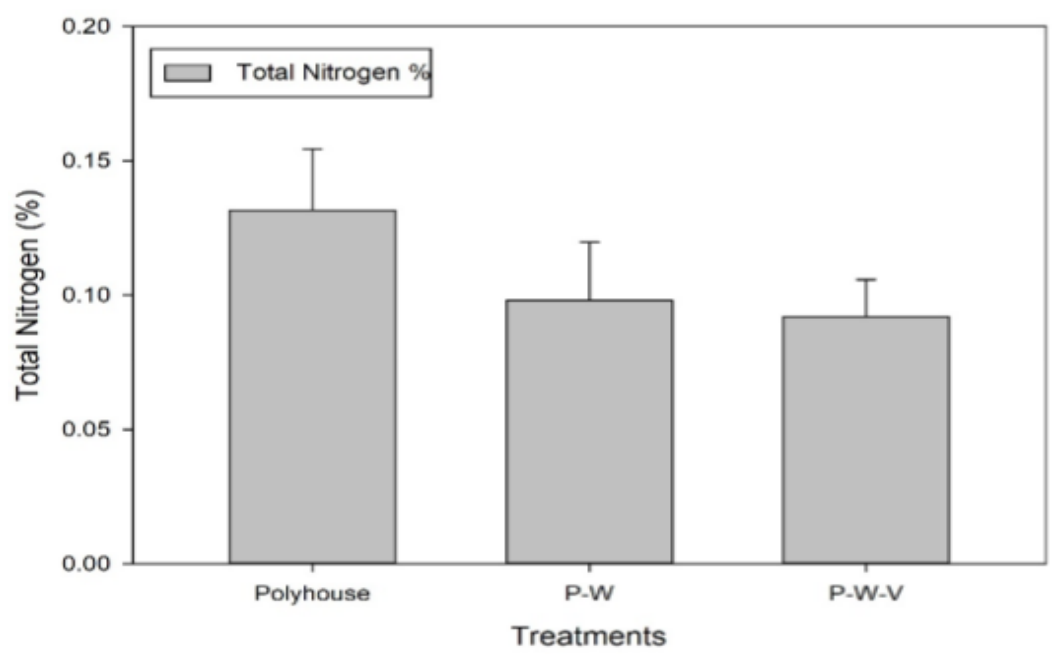

Figure-5. Total Nitrogen (N\%) under three different cropping systems.

\subsection{Carbon Nitrogen (CN) Ratio}

Carbon and nitrogen interaction is an important chemistry at ecosystem level as there can be shared substrate and dependency of availability of carbon and nitrogen [40]. CN ratio can influence plants growth. Fertilization, cropping systems and various management practices tend to affect the soil CN ratio [41]. Our findings showed a significant increase in $\mathrm{CN}$ ratio under polyhouse (Treatment 1) as compared to Paddy-Wheat. CN ratio of paddywheat system was at par with vegetable incorporated paddy-wheat system (Treatment 3) Table 2. Our results of $\mathrm{CN}$ ratio are similar with previous study [41]. Carbon nitrogen ratio is one of the common parameters used to estimate the balance of carbon and nitrogen in the soil. The carbon content in the organic matter is always greater than nitrogen in the soil [42].

Table-2. Effect of cropping system on soil chemical properties.

\begin{tabular}{|c|c|c|c|c|c|c|c|}
\hline Treatments & Treatment Details & $\mathrm{pH}$ & OM \% & $\mathrm{P} \mathrm{mg/kg}$ & $\mathrm{K} \mathrm{mg/kg}$ & TN \% & C:N ratio \\
\hline Tunnel & Polyhouse Cultivation & $4.71^{b}$ & $2.39^{\mathrm{a}}$ & $29.24^{\mathrm{a}}$ & 109.52 & $0.13^{\mathrm{a}}$ & $10.55^{\mathrm{a}}$ \\
\hline P-W & Paddy-Wheat & $5.39^{\mathrm{a}}$ & $1.60^{\mathrm{b}}$ & $4.48^{b}$ & 88.04 & $0.097^{\mathrm{b}}$ & $9.58^{b}$ \\
\hline P-W-V & $\begin{array}{l}\text { Paddy-Wheat-Season } \\
\text { vegetables }\end{array}$ & $5.33^{\mathrm{a}}$ & $1.62^{b}$ & $6.97^{\mathrm{c}}$ & 91.04 & $0.091^{\mathrm{b}}$ & $10.19^{\mathrm{ab}}$ \\
\hline$P$ value & & $*$ & * & * & 0.153 & * & 0.07 \\
\hline CV \% & & 4.09 & 18.30 & 41.89 & 30.56 & 17.12 & 10.16 \\
\hline LSD & & 0.18 & 0.29 & 4.86 & 25.12 & 0.02 & 0.88 \\
\hline SEM $( \pm)$ & & 0.08 & 0.13 & 2.23 & 11.53 & 0.007 & 0.40 \\
\hline
\end{tabular}




\subsection{Correlation between Soil Parameters}

Soil $\mathrm{pH}$ was found to have negative correlation with all parameters. It has significant high negative correlation with available phosphorus $(\mathrm{r}=-0.81, p<0.05)$ Figure 6. Previous studies have reported significant negative relationship between $\mathrm{pH}$ and available phosphorus [43]. Phosphorus can bind to several cations in the soil [43] which can lead to negative relation between soil $\mathrm{pH}$ and phosphorous viability in the soil. $\mathrm{pH}$ had negative low correlation with available potassium $(\mathrm{r}=-0.37, p=0.14)$, total nitrogen $(\mathrm{r}=-0.4, \mathrm{p}>0.05)$ and organic matter $(\mathrm{r}=-$ 0.49, p<0.05) Figure 6. Acidic soil pH affects decomposition of added organic matter [44] which might result to significant negative relation between soil $\mathrm{pH}$ and organic matter content in the soil. Soil organic matter has low correlation with available potassium $(\mathrm{r}=0.44, \mathrm{p}>0.05)$. While soil organic matter has very strong correlation with available phosphorus $(\mathrm{r}=0.78, \mathrm{p}<0.05)$ and total nitrogen $(\mathrm{r}=0.93, \mathrm{p}<0.05)$ Figure 6. The strong correlation between soil organic matter and available phosphorus could be due to $\mathrm{P}$ is contained in organic matter [45] which can increase soil P availability. Similarly, organic matter contains lager amount of nitrogen [46] which may lead to significant positive relationship between organic matter and soil nitrogen in our study. Likewise, total nitrogen was moderately correlated to available phosphorus $(\mathrm{r}=0.67, \mathrm{p}<0.05)$ and has lower correlation with available potassium $(\mathrm{r}=0.38, \mathrm{p}>0.05)$. Previous studies have reported significant relationship between nitrogen and available phosphorus similar to our results [47].

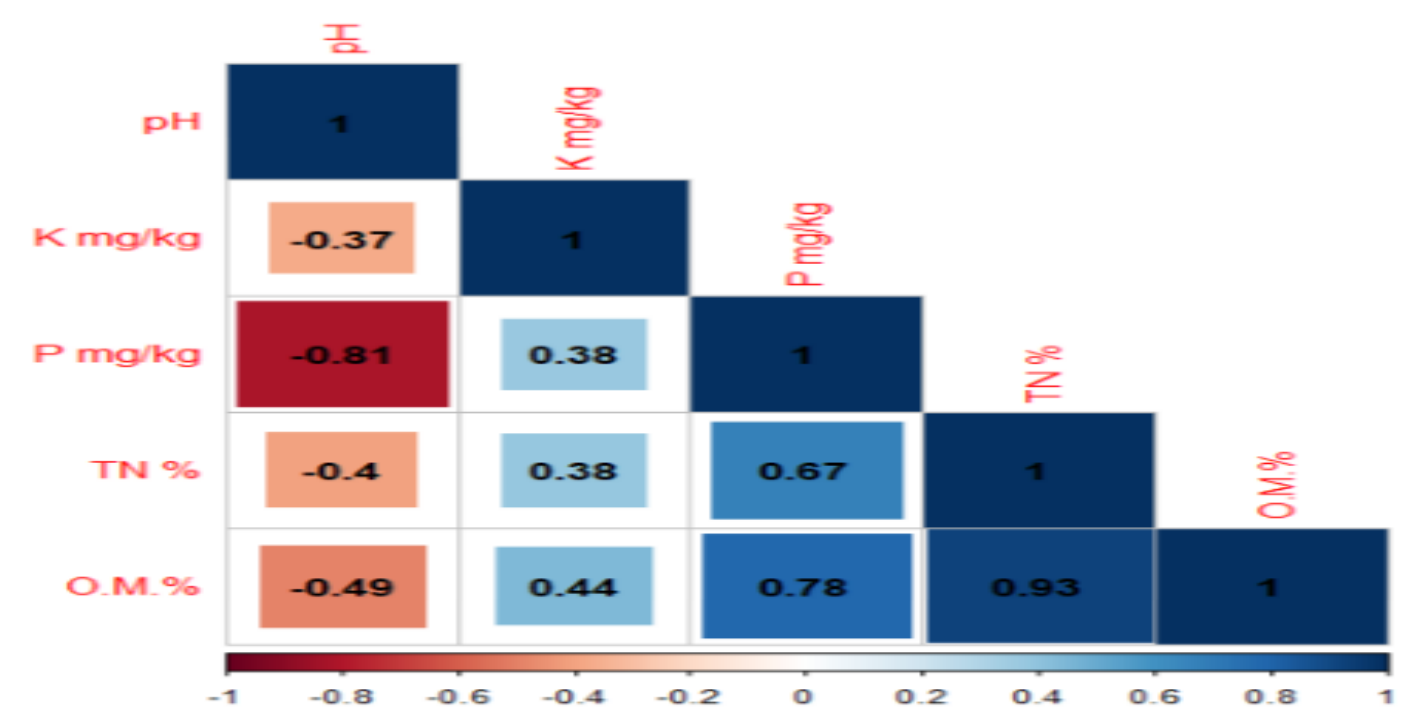

Figure-6. Correlation heatmap between soil parameter under different cropping system at Changunarayan, Bhaktapur, Nepal.

\section{CONCLUSION}

Soil under polyhouse showed increased accumulation of soil organic matter (\%), total nitrogen (\%), available phosphorus $\left(\mathrm{mgkg}^{-1}\right)$, and available potassium $\left(\mathrm{mgkg}^{-1}\right)$, while decreased soil $\mathrm{pH}$ was observed. In addition, incorporation of vegetable in paddy-wheat system has also increased accumulation of soil phosphorus and consistently raise other nutrient status. Thus, it can be argued that, intensive input cultivation system like farming under polyhouse can increase accumulation of soil organic matter (\%), total nitrogen (\%), available phosphorus $\left(\mathrm{mgkg}^{-1}\right)$, and available potassium $\left(\mathrm{mgkg}^{-1}\right)$ in cost of soil acidity. Similarly, incorporation of vegetable rotation practice in paddy-wheat system also can produce positive effect on soil health.

Funding: The authors thanks Ambit Research and Development for financial support in sample collection and laboratory analysis.

Competing Interests: The authors declare that they have no competing interests.

Acknowledgement: The authors would like to acknowledge all the volunteers who participated in soil sample collections, lab technicians who performed lab tests and owner of farms of study area who helped providing samples and information regarding agricultural practices. 


\section{REFERENCES}

[1] S. R. Reddy, Principles of agronomy, 4th ed. India: Kalyani Publishers, 2014.

[2] H. Blanco-Canqui and R. Lal, Soil and water conservation. In Principles of soil conservation and management. Dordrecht: Springer, 2010 .

[3] W. Jokela, J. Posner, J. Hedtcke, T. Balser, and H. Read, "Midwest cropping system effects on soil properties and on a soil quality index," Agronomy Journal, vol. 103, pp. 1552-1562, 2011.Available at: https://doi.org/10.2 134/agronj2010.0454.

[4] D. L. Karlen, M. Mausbach, J. W. Doran, R. Cline, R. Harris, and G. Schuman, "Soil quality: A concept, definition, and framework for evaluation (a guest editorial)," Soil Science Society of America Journal, vol. 61, pp. 4-10, 1997.Available at: https://doi.org/10.2136/sssaj1997.03615995006100010001x.

[5] D. L. Karlen, S. S. Andrews, B. J. Weinhold, and J. W. Doran, "Soil quality: Humankind's foundation for survival a research editorial by conservation professionals," Journal of Soil and Water Conservation, vol. 58, pp. 171-179, 2003.

[6] J. L. Hatfield, T. J. Sauer, and R. M. Cruse, "Soil: The forgotten piece of the water, food, energy nexus," Advances in Agronomy, vol. 143, pp. 1-46, 2017.

[7] V. A. Laudicina, A. Novara, V. Barbera, M. Egli, and L. Badalucco, "Long-term tillage and cropping system effects on chemical and biochemical characteristics of soil organic matter in a Mediterranean semiarid environment," Land Degradation $\mathcal{E}^{2}$ Development, vol. 26, pp. 45-53, 2015.Available at: https://doi.org/10.1002/ldr.2293.

[8] R. Haynes, "Interactions between soil organic matter status, cropping history, method of quantification and sample pretreatment and their effects on measured aggregate stability," Biology and Fertility of Soils, vol. 30, pp. 270-275, 2000.Available at: https://doi.org/10.1007/s003740050002.

[9] G. B. Tesfahunegn and T. A. Gebru, "Variation in soil properties under different cropping and other land-use systems in Dura catchment, Northern Ethiopia," PloS one, vol. 15, p. e0222476, 2020.Available at: https://doi.org/10.1371/journal.pone.0222476.

[10] N. Loria, S. Bhardwaj, and C. K. Ndungu, "Impact of cropping systems on soil properties, nutrient availability and their carbon sequestration potential in Shiwalik hills of Himachal Pradesh," Journal of Applied and Natural Science, vol. 8, pp. 1479-1484, 2016.Available at: https://doi.org/10.31018/jans.v8i3.987.

[11] R. Shrestha, J. Ladha, and S. Gami, "Total and organic soil carbon in cropping systems of Nepal," Nutrient Cycling in Agroecosystems, vol. 75, pp. 257-269, 2006.Available at: https://doi.org/10.1007/s10705-006-9032-z.

[12] S. Shrestha, "Crisis area study," Mountain Farming System, International Center for Integrated Mountain Development. Discussion Paper No. 321992.

[13] S. Maskey, R. Shrestha, B. Shrestha, B. Tripathi, T. Munankarmy, Y. Khadka, Y. Bhattarai, and S. Shrestha, Strategies for soil fertility research in the hills of Nepal. Khumaltar, Lalitpur, Nepal: Soil Science Division, NARC, 2000.

[14] R. B. Ojha, S. Shrestha, Y. G. Khadka, and D. Panday, "Potassium nutrient response in the rice-wheat cropping system in different agro-ecozones of Nepal," PloS one, vol. 16, p. e0248837, 2021.Available at: https://doi.org/10.1371/journal.pone.0248837.

[15] J. M. Bremner and C. S. Mulvaney, Nitrogen total. Methods of soil analysis, 2nd ed. vol. 9. Madison, WI, USA: American Society of Agronomy, 1982.

[16] S. R. Olsen, Estimation of available phosphorus in soils by extraction with sodium bicarbonate: US department of agriculture. Washinton D.C, U.S: National Government Publication, 1954.

[17] R. Simard, "Ammonium acetate-extractable elements," Soil Sampling and Methods of Analysis, vol. 1, pp. 39-42, 1993.

[18] SMD, "Manual for soil and fertilizer analysis," pp. 5-6, 2017.

[19] A. Walkley and I. A. Black, "An examination of the degtjareff method for determining soil organic matter, and a proposed modification of the chromic acid titration method," Soil Science, vol. 37, pp. 29-38, 1934.Available at: https://doi.org/10.1097/00010694-193401000-00003.

[20] M. L. Jackson, Soil chemical analysis. New Delhi, India: Prentice Hall of India Pvt. Ltd, 1973. 
[21] B. Ramamoorthy and J. Bajaj, "Available nitrogen, phosphorus and potassium status of Indian soils," Fertiliser News, vol. 14, pp. 25-36, 1969.

[22] A. Wallace, "Soil acidification from use of too much fertilizer," Communications in Soil Science and Plant Analysis, vol. 25, pp. 87-92, 1994.Available at: https://doi.org/10.1080/00103629409369010.

[23] M. T. F. Wong and R. S. Swift, "Role of organic matter in alleviating soild acidity. Handbook of soil acidity," ed New York, U.S: CRC Press, 2003, pp. 337-358.

[24] N. K. Sinha, U. K. Chopra, and A. K. Singh, "Cropping system effects on soil quality for three agro-ecosystems in India," Experimental Agriculture, vol. 50, pp. 32 1-342, 2014.Available at: https://doi.org/10.1017/s001447971300046x.

[25] D. Panday, R. B. Ojha, D. Chalise, S. Das, and B. Twanabasu, "Spatial variability of soil properties under different land use in the Dang district of Nepal," Cogent Food \& Agriculture, vol. 5, p. 1600460, 2019.Available at: https://doi.org/10.1080/2331 1932.2019.1600460.

[26] P. P. Padhi, K. Chiranjeeb, M. Das, T. Behera, and A. P. Mishra, "Fertilizer use and soil acidity," Biomolcule Reports, $\mathrm{BR} / 02 / 19 / 172020$.

[27] K. Singh, Vegetable crop production technology. Kathmandu, Nepal: Samikshya Publications, 2015.

[28] R. Hijbeek, A. Pronk, M. Van Ittersum, H. ten Berge, J. Bijttebier, and A. Verhagen, "What drives farmers to increase soil organic matter? Insights from the Netherlands," Soil Use and Management, vol. 34, pp. 85-100, 2018.Available at: https://doi.org/10.1111/sum.12401.

[29] E. Russell, "The role of organic matter in soil fertility," Philosophical Transactions of the Royal Society of London. B, Biological Sciences, vol. 281, pp. 209-219, 1977.

[30] C. Martius, H. Tiessen, and P. L. G. Vlek, The management of organic matter in tropical soils: what are the priorities?. In Managing organic matter in tropical soils: Scope and limitations. Dordrecht: Springer, 2001.

[31] M. K. Rai, B. Paudel, Y. Zhang, N. R. Khanal, P. Nepal, and H. L. Koirala, "Vegetable farming and farmers' livelihood: Insights from Kathmandu Valley, Nepal," Sustain, vol. 11, pp. 1-17, 2019.Available at: https://doi.org/10.3390/su1 1030889.

[32] J. Glanz, Saving our soil: Solutions for sustaining earth's vital resource. U.S.: Johnson Books, 1995.

[33] H. Tian, J. Qiao, Y. Zhu, X. Jia, and M. a. Shao, "Vertical distribution of soil available phosphorus and soil available potassium in the critical zone on the Loess Plateau, China," Scientific Reports, vol. 11, pp. 1-10, 2021.Available at: https://doi.org/10.1038/s41598-021-82677-4.

[34] D. Khadka, S. Lamichhane, D. Tiwari, and K. Mishra, "Assessment of soil fertility status of national rice research program, hardinath, dhanusha, Nepal," International Journal of Agricultural and Environmental Research, vol. 3, pp. 86$105,2017$.

[35] D. Menezes-Blackburn, C. Giles, T. Darch, T. S. George, M. Blackwell, M. Stutter, C. Shand, D. Lumsdon, P. Cooper, and R. Wendler, "Opportunities for mobilizing recalcitrant phosphorus from agricultural soils: A review," Plant and Soil, vol. 427, pp. 5-16, 2018.Available at: https://doi.org/10.1007/s11104-017-3362-2.

[36] I. Cakmak, "Potassium for better crop production and quality," Plant and Soil, vol. 335, pp. 1-2, 2010.

[37] V. Torres-Olivar, O. G. Villegas-Torres, M. L. Domínguez-Patiño, H. Sotelo-Nava, A. Rodríguez-Martínez, R. M. Melgoza-Alemán, L. A. Valdez-Aguilar, and I. Alia-Tejacal, "Role of nitrogen and nutrients in crop nutrition," Journal of Agricultural Science and Technology. B, vol. 4, pp. 29-37, 2014.

[38] D. Khadka, S. Lamichhane, K. P. Bhurer, J. N. Chaudhary, M. F. Ali, and L. Lakhe, "Soil fertility assessment and mapping of regional agricultural research station, Parwanipur, Bara, Nepal," Journal of Nepal Agricultural Research Council, vol. 4, pp. 33-47, 2018.Available at: https://doi.org/10.3126/jnarc.v4i1.19688.

[39] G. Shrestha, "Soil properties and soil management practices in commercial organic and conventional vegetable farms in Kathmandu valley," Nepal Journal of Science and Technology, vol. 15, pp. 13-22, 2014.Available at: https://doi.org/10.3126/njst.v15i1.12005. 
[40] X. Xu, H. Tian, and D. Hui, "Convergence in the relationship of $\mathrm{CO} 2$ and $\mathrm{N} 2 \mathrm{O}$ exchanges between soil and atmosphere within terrestrial ecosystems," Global Change Biology, vol. 14, pp. 1651-1660, 2008.Available at: https://doi.org/10.1111/j.1365-2486.2008.01595.x.

[41] X. Deng, W. Ma, Z. Ren, M. Zhang, M. L. Grieneisen, X. Chen, X. Fei, F. Qin, Y. Zhan, and X. Lv, "Spatial and temporal trends of soil total nitrogen and $\mathrm{C} / \mathrm{N}$ ratio for croplands of East China," Geoderma, vol. 361, p. 114035, 2020.Available at: https://doi.org/10.1016/j.geoderma.2019.114035.

[42] J. Webb, P. Sørensen, G. Velthof, B. Amon, M. Pinto, L. Rodhe, E. Salomon, N. Hutchings, P. Burczyk, and J. Reid, "An assessment of the variation of manure nitrogen efficiency throughout Europe and an appraisal of means to increase manure-N efficiency," Advances in Agronomy, vol. 119, pp. 371-442, 2013.Available at: https://doi.org/10.1016/b978-012-407247-3.00007-x.

[43] B. Da Silva Cerozi and K. Fitzsimmons, "The effect of $\mathrm{pH}$ on phosphorus availability and speciation in an aquaponics nutrient solution," Bioresource Technology, vol. 219, pp. 778-781, 2016.Available at: https://doi.org/10.1016/j.biortech.2016.08.079.

[44] P. Motavalli, C. Palm, W. Parton, E. Elliott, and S. Frey, "Soil pH and organic C dynamics in tropical forest soils: Evidence from laboratory and simulation studies," Soil Biology and Biochemistry, vol. 27, pp. 1589-1599, 1995.Available at: https://doi.org/10.1016/0038-0717(95)00082-p.

[45] C. N. Guppy, N. Menzies, P. W. Moody, and F. Blamey, "Competitive sorption reactions between phosphorus and organic matter in soil: A review," Soil Research, vol. 43, pp. 189-202, 2005.Available at: https://doi.org/10.1071/sr04049.

[46] L. Abbadie, A. Mariotti, and J.-C. Menaut, "Independence of savanna grasses from soil organic matter for their nitrogen supply," Ecology, vol. 73, pp. 608-613, 1992.Available at: https://doi.org/10.2307/1940766.

[47] J. M. Abell, D. Özkundakci, D. P. Hamilton, and S. D. Miller, "Relationships between land use and nitrogen and phosphorus in New Zealand lakes," Marine and Freshwater Research, vol. 62, pp. 162-175, 2011.Available at: https://doi.org/10.1071/mf10180.

Views and opinions expressed in this article are the views and opinions of the author(s), Current Research in Agricultural Sciences shall not be responsible or answerable for any loss, damage or liability etc. caused in relation to/arising out of the use of the content. 